\title{
The Study of The Electrical Conductivity and Activation Energy on Conductive Polymer Materials
}

\author{
Balqyz Lovelila Hermansyah Azari ${ }^{1, a}$, Totok Wicaksono ${ }^{1}$, Jihan Febryan \\ Damayanti ${ }^{1}$, Dheananda Fyora Hermansyah Azari ${ }^{2}$ \\ ${ }^{1}$ Department of Physics, Faculty of Mathematics and Natural Sciences, University of Jember, \\ Jalan Kalimantan No. 37, Jember 68121, Indonesia \\ 2Department of Agrotechnology, Faculty of Agriculture, University of Trunojoyo Madura, Jalan \\ Raya Telang, Kamal, Bangkalan, Madura 69162, Indonesia \\ aazharibalqyz1820@gmail.com
}

\begin{abstract}
Conductive Polymers are one of the interesting topics to be developed in recent years. Conductive polymers can combine the properties of polymers and the electrical properties of metals. Research related to the electrical properties of conductive polymers, including electrical conductivity measurements and determination of activation energy has been carried out. This study aims to determine the effect of addition mass fraction of activated carbon into the nylon polymer on the conductive polymer material based on the electrical conductivity and activation energy. The variations of activated carbon used are $0 \%, 1 \%, 2 \%, 3 \%, 4 \%, 5 \%, 6 \%, 7 \%, 8 \%, 9 \%, 10 \%(\mathrm{wt} / \mathrm{V})$. The conductive polymer from nylon polymer and activated carbon is made by casting solution method. The electrical conductivity measurement of the conductive polymer and the activation energy was carried out using the parallel plate method. The value of electrical conductivity increased from $5.62 \times 10^{-9} \pm 1.89 \times 10^{-10} \mathrm{~S} / \mathrm{cm}$ for the pure nylon to $2.51 \times 10^{-8} \pm 2.87 \times 10^{-10} \mathrm{~S} / \mathrm{cm}$ for the addition of mass fraction of activated carbon $8 \% \mathrm{wt} / \mathrm{V}$. Meanwhile, there was a decrease in the addition of $9 \% \mathrm{wt} / \mathrm{V}$ and $10 \% \mathrm{wt} / \mathrm{V}$ of mass fraction of activated carbon, which were $2.36 \times 10^{-8} \pm 3.47 \times 10^{-10} \mathrm{~S} / \mathrm{cm}$ and $2.28 \times 10^{-8} \pm 4.01 \times 10^{-10} \mathrm{~S} / \mathrm{cm}$. The activation energy of conductive polymer obtained decreased with increasing in the mass fraction of the activated carbon into the nylon polymer. The activation energy for the pure nylon was $0.0189 \mathrm{eV}$ and $0.0127 \mathrm{eV}$ for the addition of $8 \% \mathrm{wt} / \mathrm{V}$ mass fraction of activated carbon. Meanwhile, there was an increase in the addition of $9 \% \mathrm{wt} / \mathrm{V}$ and $10 \% \mathrm{wt} / \mathrm{V}$ mass fractions of activated carbon of $0.0145 \mathrm{eV}$ and $0.0150 \mathrm{eV}$, respectively.
\end{abstract}

Keywords: Conductive Polymer, Nylon, Activated Carbon, Electrical Conductivity, Activation Energy.

\section{Introduction}

Conductive polymers (CPs) have now become one of the interesting topics to be developed on an industrial scale and for commercial purposes. Conductive polymers have received a lot of attention because they have similar electrical and electrochemical properties to semiconductors and metals [1]. Conductive polymers are an alternative that can be used to overcome the problem of storing electrical energy [2]. Conductive polymers have excellent characteristics such as light material weight, low density, corrosion resistance, flexible structure, good conductivity and easy to manufacture so that their production costs are relatively cheaper. Conductive polymers have many advantages and can be applied in several ways such as optoelectronic devices, biosensors, rechargeable battery electromagnetic devices and supercapacitors [3]. 
Conductive polymers are a polymer filled with a conductive material such as carbon, metal flakes or fibers and so on. The formation of a conductive polymer by adding a conductive material to the polymer matrix can improve the characteristics of the resulting conductive polymer material in terms of morphology, electrical, thermal, and mechanical properties [4]. Several studies related to conductive polymers have been carried out including the study of the electrical conductivity of conductive materials from a mixture of aluminum flakes and nylon polymers [5], the mechanical properties of the functionalization effect of carbon nanotubes from water hyacinth into nylon polymers [6], the effect of addition of carbon nanotubes from water hyacinth into nylon polymers on increasing the value of electrical conductivity and activation energy [7], and synthesized conductive polymer materials from a mixture of nylon and graphene [8]. Based on several studies related to conductive polymer materials that have been carried out, nylon polymers with added conductive materials showed better performance than those without added conductive materials. Therefore, in this study, a conductive polymer material was synthesized from a mixture of nylon polymer and activated carbon.

Based on physical, chemical, and structural properties, nylon is a polyamide compound, and it is very possible to be used as a polymer matrix [9]. Nylon is a polymer compound that has an amide group on each repeat unit, so nylon is also called a polyamide compound [10]. The choice of nylon raw material as a polymer matrix is due to its relatively low price, good mechanical, thermal and chemical properties [11].

Activated carbon is carbon that has been activated chemically, physically or both. This activation process produces a carbon structure with open pores, a larger carbon surface area and a higher adsorption capacity [12]. Activated carbon has been widely used as an electrode material because it is considered to have a high specific surface area so that its pore structure can also be utilized, especially to facilitate the formation of an electric double layer on the electrode surface, chemical resistance, good electrical conductivity and affordable price [13]. Coconut shell is the best material that can be made into activated carbon because activated carbon made from coconut shell has many micropores, low ash content, high water solubility and high reactivity [14].

Measurement of electrical properties is one way to determine the characteristics of a physically conductive polymer material. One of the electrical properties that can be measured from a conductive polymer material is the electrical conductivity and activation energy, where it can be seen that the rate of stability of charge carriers in a material will accelerate with changes in temperature, this can be shown by the smaller the value of the activation energy. Electrical conductivity is the ability of a material to conduct electric current as indicated by the measured value [15]. So in this research, electrical conductivity and activation energy were measured on conductive polymer materials from a mixture of nylon and activated carbon. This research is expected to provide information regarding the addition of the right mass fraction of activated carbon into the nylon polymer matrix to obtain the best conductive polymer material measured by the electrical properties.

\section{Theoretical Background}

Electrical conductivity is a measure of the ability of a material to conduct electric current. If there is an electric potential difference at the ends of the conductor, the charges will move to produce an electric current. The value of electrical conductivity is also strongly influenced by the moisture content, density and structure of the material. Synthetic and natural materials can be 
classified into three, namely, conductors, semiconductors, and insulators. The value of the electrical conductivity of the three materials is different [16].

Electrical conductivity $(\sigma)$ is inversely proportional to the value of resistivity $(\rho)$. The value of the electrical conductivity of a material depends on the properties of the material. The equation to calculate the electrical conductivity is [17] :

$\sigma=\frac{1}{\rho}=\frac{L}{A R}$

Where $\sigma$ is the electrical conductivity $(\mathrm{S} / \mathrm{cm}), \rho$ is the electrical resistivity $(\Omega . \mathrm{cm}), R$ is the resistance of the conductive polymer material $(\Omega), L$ is the thickness of the conductive polymer material $(\mathrm{cm}), A$ is the cross-sectional area of the conductive polymer material $\left(\mathrm{cm}^{2}\right)$.

The activation energy $(E \alpha)$ is the energy required to reach the transition state of the complex supplied from outside the system [18]. Activation energy can be used as a reference to determine the minimum amount of energy required to activate a reaction as a result of the meeting of molecules in a collision or vibration [19]. The activation energy is influenced by several factors, namely temperature, frequency and catalyst.

The relationship between electrical conductivity and activation energy is expressed by the following Arrhennius equation:

$\sigma=\sigma_{0} \exp \left(-\frac{E \alpha}{k_{b} T}\right)$

where is $\sigma_{0}$ the initial electrical conductivity, $E \alpha$ is the activation energy $(\mathrm{eV}), k_{b}$ is the Boltzman constant $\left(8.62 \times 10^{-5} \mathrm{eV} / \mathrm{K}\right)$, and $T$ is the absolute temperature $(\mathrm{K})$ [7].

\section{Materials and Methods}

a.) Synthesis of Activated Carbon

The coconut shell is cleaned and washed with water, then allowed to dry in the sun. The clean and dry coconut shell is then burned until it becomes charcoal. The charcoal of coconut shell is mashed using a mortar until it becomes powder and sieved using a 200-mesh sieve. The activation process is carried out by soaking coconut shell charcoal into a $5 \mathrm{~N} \mathrm{H}_{2} \mathrm{SO}_{4}$ solution for 12 hours to become activated carbon [20]. Then the activated carbon is filtered which has been coated with filter paper. The activated carbon was then washed with distilled water until the $\mathrm{pH}$ was neutral. Then the activated carbon was dried in an oven at $110{ }^{\circ} \mathrm{C}$ for 3 hours. The activated carbon from coconut shell is cooled at room temperature to be ready for use.

\section{b.) Synthesis of Conductive Polymer Materials}

The conductive polymer material process is made using the casting solution method. The polymer was made by mixing nylon with activated carbon into $20 \mathrm{ml}$ of $25 \%(\mathrm{v} / \mathrm{v}) \mathrm{HCl}$ and $2 \mathrm{ml}$ of acetone. The variation of mass variation of activated carbon as much as $1 \% ; 2 \% ; 3 \% ; 4 \%$; $5 \% ; 6 \% ; 7 \% ; 8 \% ; 9 \% ; 10 \%$. Then a mixture of nylon and activated carbon was stirred using a magnetic stirrer at a speed of $350 \mathrm{rpm}$ for \pm 1 hour. The solution is printed on a glass plate then immersed in distilled water until it forms a solid. The polymer that has been formed is dried for \pm 12 hours. 
c.) The Electrical measurement of Conductive Polymer Material

In this research, the measurement of the electrical conductivity and activation energy of conductive polymer material use the parallel plate capacitor plate method. Parallel plate capacitor is made of PCB plates with a size of $3.1 \times 3.1 \mathrm{~cm}$. The electrical conductivity measurements are made by setting up a function generator at a frequency of $1 \mathrm{kHz}$ and a digital multimeter is connected to the circuit. The measured voltage value on a digital multimeter is then recorded for each sample tested. Meanwhile, the activation energy of the conductive polymer material is obtained from the measurement of the electrical conductivity at various temperatures. The temperature variations used ranged from $25^{\circ} \mathrm{C}-100^{\circ} \mathrm{C}$.

\section{Results and Discussion}

Activated carbon is one of the conductive materials that can increase the electrical conductivity. In this study, activated carbon produced from coconut shells has an electrical conductivity value of $2.36 \times 10^{-8} \pm 5.39 \times 10^{-10} \mathrm{~S} / \mathrm{cm}$. The value of the electrical conductivity of coconut shell activated carbon resulting from this study lies in the area of the electrical conductivity value of the semiconductor material, which is at a value of $10^{-8} \mathrm{~S} / \mathrm{cm}$ to $10^{3} \mathrm{~S} / \mathrm{cm}$ [21], so that coconut shell activated carbon has the potential to be used as conductive material.

In this study, the mass fraction of activated carbon was added to the nylon polymer to obtain the best conductive polymer based on electrical measurements. The synthesis of conductive polymer material in this study uses the casting solution method. The casting solution process is carried out by printing the polymer solution into the desired sheet and put in a fluid medium to remove solvent and precipitate the polymer [22].

Electrical conductivity is a measure of the ability of a material to conduct electrical current [17]. The result of the electrical conductivity of conductive polymer materials are shown in Table 1. The measurement results show that the addition of the mass fraction of activated carbon into the nylon polymer increases the value of the electrical conductivity of the conductive polymer material. The greater the value of electrical conductivity indicates that the material is better at conducting electricity [15]. Based on the research, it was found that nylon polymer without the addition of coconut shell activated carbon mass fraction (0 wt\%) had an electrical conductivity value of $5.62 \times 10^{-9} \pm 1.89 \times 10^{-10} \mathrm{~S} / \mathrm{cm}$. From the previous research obtained the results of the electrical conductivity of pure nylon of $2.7 \times 10^{-9} \mathrm{~S} / \mathrm{cm}$ [7] and $(0.66 \pm 0.04) \times 10^{-9} \mathrm{~S} / \mathrm{cm}$ [23]. The different results of the electrical conductivity values obtained may be due to the use of nylon raw materials and the polymer fabrication method used. However, the results obtained from measuring the electrical conductivity of nylon polymers are not much different from previous studies.

Addition of mass fraction of activated carbon to nylon polymer increases the value of electrical conductivity one order compared to pure nylon polymer (without the addition of activated carbon). The electrical conductivity of the conductive polymer material obtained in this study ranged from $9.77 \times 10^{-9} \pm 3.98 \times 10^{-10} \mathrm{~S} / \mathrm{cm}$ to $2.28 \times 10^{-8} \pm 4.01 \times 10^{-10} \mathrm{~S} / \mathrm{cm}$. Based on Table 1 , the addition of the mass fraction of activated carbon in this study increased from the addition of the mass fraction of the conductive polymer sample B (1 wt\%) to the conductive polymer sample I (8 $\mathrm{wt} \%$ ), respectively $1.28 \times 10^{-8} \pm 3.66 \times 10^{-10} \mathrm{~S} / \mathrm{cm}, 1.31 \times 10^{-8} \pm 7.01 \times 10^{-10} \mathrm{~S} / \mathrm{cm}, 1.63 \times 10^{-8} \pm$ $6.97 \times 10^{-10} \mathrm{~S} / \mathrm{cm}, 1.71 \times 10^{-8} \pm 4.54 \times 10^{-10} \mathrm{~S} / \mathrm{cm}, 1.94 \times 10^{-8} \pm 1.73 \times 10^{-10} \mathrm{~S} / \mathrm{cm}, 2.34 \times 10^{-8} \pm 1.69 \times$ $10^{-10} \mathrm{~S} / \mathrm{cm}, 2.51 \times 10^{-8} \pm 2.87 \times 10^{-10} \mathrm{~S} / \mathrm{cm}$. Meanwhile, the value of electrical conductivity 
decreased with the addition of mass fractions 9 wt\% (sample $\mathrm{J}$ ) and $10 \mathrm{wt} \%$ (sample $\mathrm{K}$ ), which was $2.36 \times 10^{-8} \pm 3.47 \times 10^{-10} \mathrm{~S} / \mathrm{cm}$ and $2,28 \times 10^{-8} \pm 4.01 \times 10^{-10} \mathrm{~S} / \mathrm{cm}$.

Table 1 . The electrical conductivity of conductive polymer materials at $25^{\circ} \mathrm{C}$

\begin{tabular}{ccc}
\hline $\begin{array}{c}\text { Conductive Polymer } \\
\text { Sample }\end{array}$ & $\begin{array}{c}\text { Activated Carbon } \\
\text { Concentration (wt\%) }\end{array}$ & $\begin{array}{c}\text { Electrical Conductivity } \\
\boldsymbol{\sigma}=\overline{\boldsymbol{\sigma}} \pm \Delta \boldsymbol{\sigma}(\mathbf{S} / \mathbf{c m})\end{array}$ \\
\hline A & 0 & $5.62 \times 10^{-9} \pm 1.89 \times 10^{-10}$ \\
B & 1 & $9.77 \times 10^{-9} \pm 3.98 \times 10^{-10}$ \\
C & 2 & $1.28 \times 10^{-8} \pm 3.66 \times 10^{-10}$ \\
D & 3 & $1.31 \times 10^{-8} \pm 7.01 \times 10^{-10}$ \\
E & 4 & $1.63 \times 10^{-8} \pm 6.97 \times 10^{-10}$ \\
F & 5 & $1.71 \times 10^{-8} \pm 4.54 \times 10^{-10}$ \\
G & 6 & $1.94 \times 10^{-8} \pm 1.73 \times 10^{-10}$ \\
H & 7 & $2.34 \times 10^{-8} \pm 1.69 \times 10^{-10}$ \\
I & 8 & $2.51 \times 10^{-8} \pm 2.87 \times 10^{-10}$ \\
J & 9 & $2.36 \times 10^{-8} \pm 3.47 \times 10^{-10}$ \\
K & 10 & $2.28 \times 10^{-8} \pm 4.01 \times 10^{-10}$ \\
\hline
\end{tabular}

The addition of carbon to the nylon polymer improves the structural arrangement of the polymer bonds and facilitates the delocalization of charge carriers resulting in an increase in the electrical conductivity [1]. The greater the value of the electrical conductivity of the conductive polymer material, the better the characteristics of the polymer in conducting electric charges. From the results of this study, it was obtained that the largest electrical conductivity was obtained from the addition of the mass fraction of activated carbon as much as 8 wt\% (sample I).

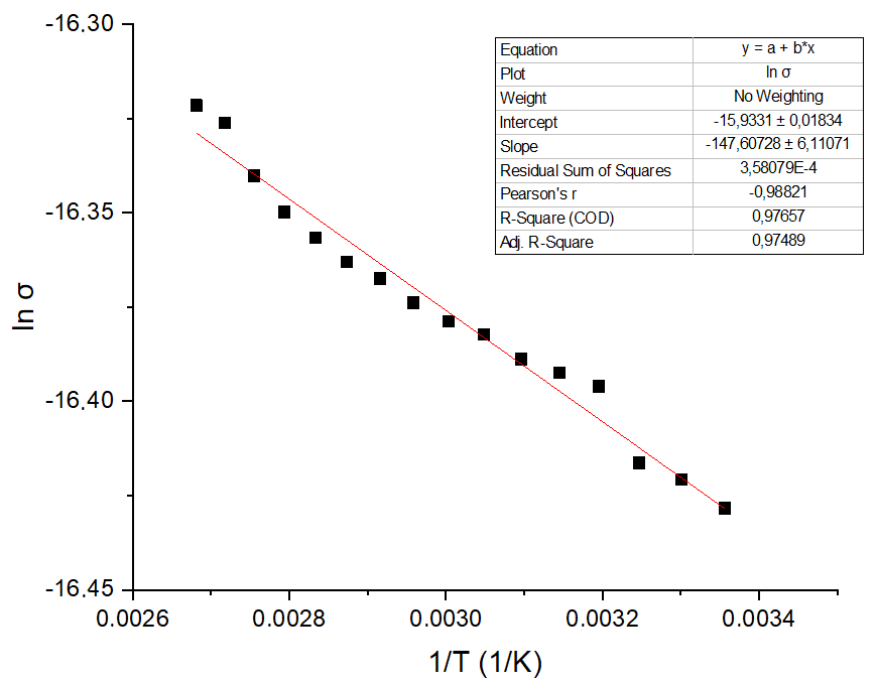

Figure 1. Slope of In $\sigma$ to $1 / T$ from conductive polymer material with addition of of mass fraction of activated carbon 8 wt\% (Sample I)

The activation energy of the conductive polymer material has obtained from the slope of the graph of the relationship In $\sigma$ to $1 / T$ in the measurement temperature range of $298 \mathrm{~K}-373 \mathrm{~K}$. Figure 1 is a graph of the relationship In $\sigma$ to $1 / T$ with a temperature range of $298 \mathrm{~K}-373 \mathrm{~K}$ on the conductive polymer of sample I. Activation energy can be used as a parameter to determine 
the minimum amount of energy used to activate a reaction as a result of the meeting of molecules in a vibration or collision while the number of collision frequencies between molecules during the reaction can be indicated by the presence of a frequency factor constant, which in this study shows the value of the initial electrical conductivity $\left(\sigma_{0}\right)$ [24]. The value of the initial electrical conductivity $\left(\sigma_{0}\right)$ in this study was obtained from the graph intercept of the relationship In $\sigma$ to $1 / T$. The values of the activation energy in this study are shown in Table 2 .

Table 2. The activation energy and the Arrhennius equation for conductive polymer materials

\begin{tabular}{cccc}
$\begin{array}{c}\text { Conductive } \\
\text { Polymer Sample }\end{array}$ & $\begin{array}{c}\text { Activated Carbon } \\
\text { Concentration (wt\%) }\end{array}$ & Ea (eV) & $\begin{array}{c}\text { Arhennius Eqution of Electrical } \\
\text { Conductivity (S/cm) }\end{array}$ \\
\hline A & 0 & 0.0189 & $\sigma=1.51 \times 10^{-7} \exp \left(-0.0353 / k_{b} T\right)$ \\
B & 1 & 0.0162 & $\sigma=1.42 \times 10^{-7} \exp \left(-0.0162 / k_{b} T\right)$ \\
C & 2 & 0.0150 & $\sigma=1.34 \times 10^{-7} \exp \left(-0.0150 / k_{b} T\right)$ \\
D & 3 & 0.0144 & $\sigma=1.34 \times 10^{-7} \exp \left(-0.0144 / k_{b} T\right)$ \\
E & 4 & 0.0142 & $\sigma=1.32 \times 10^{-7} \exp \left(-0.0147 / k_{b} T\right)$ \\
F & 5 & 0.0135 & $\sigma=1.30 \times 10^{-7} \exp \left(-0.0135 / k_{b} T\right)$ \\
G & 6 & 0.0130 & $\sigma=1.26 \times 10^{-7} \exp \left(-0.0130 / k_{b} T\right)$ \\
H & 7 & 0.0129 & $\sigma=1.28 \times 10^{-7} \exp \left(-0.0133 / k_{b} T\right)$ \\
I & 8 & 0.0127 & $\sigma=1.20 \times 10^{-7} \exp \left(-0.0170 / k_{b} T\right)$ \\
J & 9 & 0.0145 & $\sigma=1.23 \times 10^{-7} \exp \left(-0.0163 / k_{b} T\right)$ \\
K & 10 & 0.0150 & $\sigma=1.33 \times 10^{-7} \exp \left(-0.0163 / k_{b} T\right)$ \\
\hline
\end{tabular}

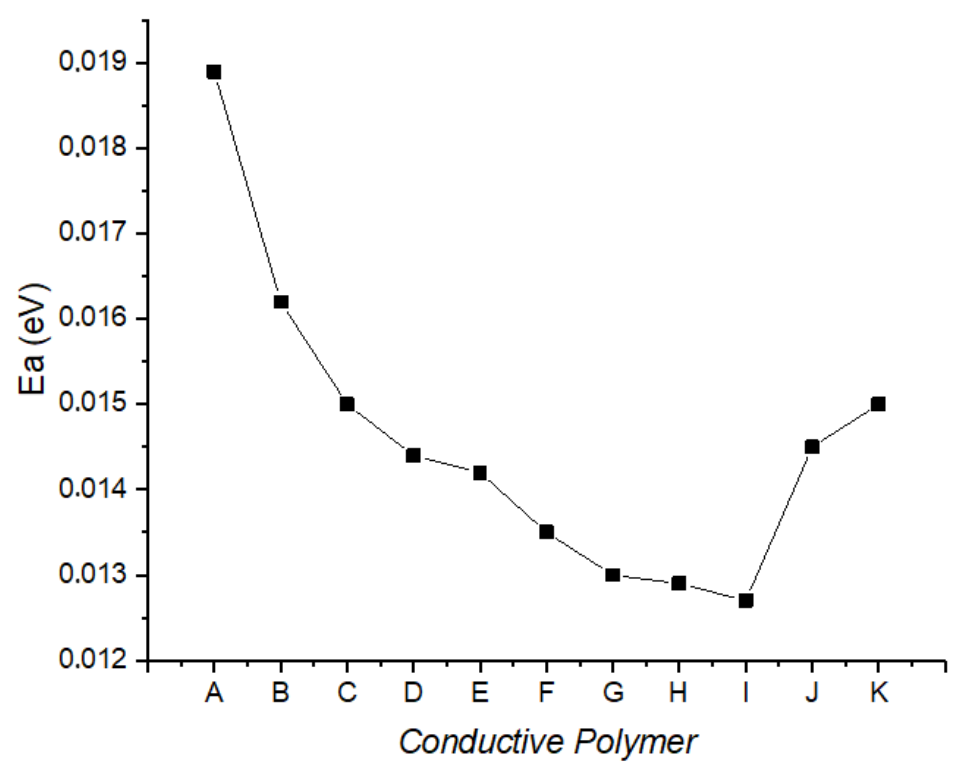

Figure 2. The activation energy of the conductive polymer materials

The parameter that has the lowest activation energy is the key [19]. From this study, the lowest activation energy value indicates the best conductive polymer materials. The value of activation energy ( $\mathrm{Ea}$ ) can be used to see the characteristics of the charge stability rate mechanism that passes through a conductive polymer material under the influence of temperature. The greater the activation energy means the rate of charge stability that passes through the conductive 
polymer material will be slower with changes in temperature (indicated by the steeper slope of the line). On the other hand, the lower the activation energy, the rate of charge stability passing through the conductive polymer material will be faster with changes in temperature (shown by a gentler slope) [25].

Based on the Figure 2, it can be seen that the addition of mass fraction of activated carbon to nylon polymer causes a decrease in activation energy compared to nylon polymer without the addition of $0 \mathrm{wt} \%$ activated carbon (sample A). The activation energy decreased starting from the addition of the mass fraction of activated carbon, $1 \mathrm{wt} \%$ (sample B), $2 \mathrm{wt} \%$ (sample C), 3 wt\% (sample D), 5 wt\% (sample F), 6 wt\% (sample G), 7 wt\% (sample H) and 8 wt\% (sample I), respectively, and increased with the addition of mass fractions of $9 \mathrm{wt} \%$ (sample $\mathrm{J}$ ) and $10 \mathrm{wt} \%$ (sample K). The increase in activation energy value with the addition of $9 \mathrm{wt} \%$ and $10 \mathrm{wt} \%$ activated carbon mass fractions may be due to the uneven dispersion of the mixture between nylon polymer and activated carbon. Since good dispersion is essential for forming conductive pathways in conductive polymeric materials, increasing the concentration of activated carbon causes the mixture to become less homogeneous. The addition of more carbon into the nylon matrix reduces the transportability of the polymer chains during the crystallization process and thus increases the activation energy [7].

The activation energy values obtained in this study ranged from $0.0189 \mathrm{eV}$ to $0.0150 \mathrm{eV}$. The highest activation energy was found in the polymer without the addition of activated carbon (sample A), which was $0.1103 \mathrm{eV}$. Meanwhile, the lowest activation energy was found in the conductive polymer with the addition of $8 \mathrm{wt} \%$ activated carbon (sample I), which was 0.0127 $\mathrm{eV}$. The activation energy of the conductive polymer can vary depending on the type of polymer, polymer characteristics (hydrophobicity), and thickness. In this study, the thickness of the conductive polymer material ranged from $0.25 \mathrm{~mm}$ to $0.28 \mathrm{~mm}$

\section{Conclusions}

The charge carrier stability rate mechanism through the conductive polymer material shows the best results based on the highest electrical conductivity value and the lowest activation energy. In this study, the value of electrical conductivity was obtained when the mass fraction of activated carbon was added as much as 8 wt\% (sample I), with a value of $\left(2.51 \times 10^{-8} \pm 1.69 \times 10^{-}\right.$

$\left.{ }^{10}\right) \mathrm{S} / \mathrm{cm}$. Meanwhile, the lowest activation energy was also obtained by adding the mass fraction of activated carbon as much as $8 \mathrm{wt} \%$ (sample I) with a value of $0.0127 \mathrm{eV}$.

\section{ACKNOWLEDGEMENTS}

The author would like to thank the LP2M University of Jember for funding the research by Hibah KeRis Komputasi Material Terapan 2021

\section{References}

[1] L. Thanh-Hai, K. Yukyung, and Y. Hyeonseok. 2017. Electrical and Electrochemical Properties of Conducting Polymers. Polymers. 9(150): 2-32.

[2] G. Nystrom, A. Razaq, M. Stromme, L. Nyholm, and A. Mihranyan.2009. Ultrafast AllPolymer Paper-Based Batteries. Nano letters. 9(10): 3635-3639. 
[3] D. Anaklı, S. Cetinkaya, and M. Karakisla. 2018. Synthesis of Conductive Polymer/Inorganic Material Composites and Characterization of Their Properties. Materials Focus. 7: 1-4.

[4] B. Sitorus, V. Suendo, and F. Hidayat. 2011. Sintesis Polimer Konduktif sebagai Bahan Baku untuk Perangkat Penyimpan Energi Listrik. Jurnal ELKHA.3(1):43-47.

[5] G. Pinto, and J. Martin. 2001. Conducting Alumunium - Filled Nylon 6 Composites. Polymer Composites. 22 (1): 65-70.

[6] Z. Xiangdong, Q. Jiao, C. Zang, and X. Cao. 2013. Effects of Functionalization MWCNTs on the Mechanical and Electrical Properties of Nylon-6 Composites. Advanced Material Research. 750-752: 127-131.

[7] F. A. Chayad, A. R. Jabur, and N. M. Jalal. 2015. Effect of MWCNT Addition on Improving the Electrical Conductivity and Activation Energy of Electrospun Nylon Films. Karbala InternationalJournal of Modern Science I.1(4): 187-193.

[8] M. I. Shueb, M. E. A. Manaf, C. T. Ratnam, N. Mohamad, and M. Mohamed. 2020. Enhancement of Mechanical and Electrical Properties in Graphene Nanoplatelet Modified Nylon 66. Malaysian Journal on Composites Science and Manufacturing. 1(1): 1-10.

[9] A. Saleh, A. L. Wiguna, and P. Afrilia.2016. Pengaruh Mesh dan Panjang Kain Nilon Terhadap Peningkatan Kadar Metana pada Purifikasi Biogas. Jurnal Teknik Kimia. 22(2): 62-69.

[10] L. Huang, and J. R. McCutcheon. 2014. Hydrophilic Nylon 6,6 Nanofibers Supported Thin Film Composite Membranes for Engineered Osmosis. Journal of Membrane Science. 457: 162-169.

[11] S. Moerniati, Aspriyanto, S. Aiman, Wahab, and Nurhasanah. 1998. Preparasi Membran Poliamida dengan Menggunakan Proses Phase Inversion. Serpong: Puslitbang Kimia Terapan LIPI.

[12] F. Pujiono, and T. A. Mulyati. 2017. Potensi Karbon Aktif dari Limbah Pertanian sebagai Material Pengolahan Air Limbah. Jurnal Wiyata: Penelitian Sains dan Kesehatan. 4(1): 3745.

[13] F. R. Tumimomor, and S. C. Palilingan. 2018. Pemanfaatan KarbonAktif dari Sabut Kelapa sebagai Elektroda Superkapasitor. Fullerene Journal of Chemistry. 3(1): 13-18.

[14] G. S. Pambayun, R. Y. E. Yulianto, M. Rachimoellah, and E. M. M. Putri. 2013. Pembuatan Karbon Aktif dari Arang Tempurung Kelapa dengan Aktivator $\mathrm{ZnCl}_{2}$ dan $\mathrm{Na}_{2} \mathrm{CO}_{3}$ sebagai Adsorben untuk Mengurangi Kadar Fenol dalam Air Limbah. Jurnal Teknik ITS. 2(1): F116-F120.

[15] Irzaman, A. Agustina, R. N. Komariah, and J. Khabibi. 2014. Electrical Properties of Indonesian Hardwood Case Study: Acacia Mangium, Switenia Macrophylla and Measopsis Eminii. Wood Research. 59 (4): 695-704. 
[16] Irzaman, R. Erviansyah, H. Syafutra, A. Maddu, and Siswadi. 2010. Studi Konduktivitas Listrik Film Tipis $\mathrm{Ba}_{0,25} \mathrm{Sr}_{0,75} \mathrm{TiO}_{3}$ yang Didadah Ferium Oksida (BFST) menggunakan Metode Chemical Solution Deposition. Berkala Fisika. 13(1): 33-38.

[17] A. Junaedi. 2011. Membran Elektrolit dari Komposit Pva-Lioh dengan Nanopartikel Silika Terdispersi. Skripsi. Semarang: Universitas Negeri Semarang.

[18] A. Asropi, N. Bintoro, J. N. W. Karyadi, S. Rahayoe, and A. D. Saputro. 2019. Kinetika Perubahan Sifat Fisik dan Kadar Tanin Biji Sorgum (Sorghum Bicolor L.) selama Perendaman. Agritech. 39(3): 222-233.

[19] Afriyanti. 2017. Pendugaan Umur Simpan Keripik Tempe Sagu menggunakan Pengemas Plastik PP dengan Metode Arrhenius. Jurnal IImu Pangan dan Hasil Pertanian. 1 (1): 71 79.

[20] P. R. Gawande, and D. J. Kaware. 2017. Characterization and Activation of Coconut Shell Activated Carbon Research Paper. International Journal of Engineering Science Invention. 6(11): 43-49.

[21] F. Destyorini, A. Suhandi, A. Subhan, and N. Indayaningsih. 2010. Pengaruh Suhu Karbonisasi Terhadap Struktur dan Konduktivitas Listrik Arang Serabut Kelapa. Jurnal Fisika. 10(2): 122-132.

[22] R. B. Fitradi. 2015. Preparasi dan Modifikasi Membran untuk Pengolahan Air. Teknik Kimia Institut Teknologi Bandung. 01-15.

[23] N. O. H. Rohmah. 2020. Effect of $\mathrm{TiO}_{2}$ Addition on The Electrical Conductivity of Nylon$\mathrm{TiO}_{2}$ Hybrid Membrane. Computational and Experimental Research in Materials and Renewable Energy (CERiMRE). 3(2): 47-52.

[24] R. Hustiani. 2016. Aplikasi Persamaan Arrhenius dan Linear untuk Pengujian Stabilitas Retensi Impact Compound Flavor Kweni Terenkapsulasi. ZIRAA'AH. 41(3): 393-402.

[25] A. D. Anggo, A. S. Fahmi, and Y. S. Darmanto. 2017. Energi Aktivasi Perubahan Nilai Free Fatty Acid pada Abon Ikan Lele Dumbo (Clarias sp) Selama Penyimpanan. Jurnal IImu Pangan dan Hasil Pertanian. 1(2): 21-28. 